\title{
CHRONOLOGY OF ITALIAN POLITICAL EVENTS, 2009
}

\section{January}

1 The court, hearing a case on appeal, cancels the request to put Salvatore Margiotta, deputy of the Partito Democratico (PD, Democratic Party), under house arrest. Conflicts arise between the PD and Antonio Di Pietro, the leader of Italia dei Valori (IdV, Italy of Values), who had voted in favor of the concession regarding the arrest.

2 Whereas in 2007 the government sector was in need of 26.5 billion euros, in 2008 that figure increased to 52.9 billion euros. Finance Minister Giulio Tremonti assures that the closing accounts for 2008 adhere to the European benchmarks.

4 Walter Veltroni (PD) describes the position of Foreign Affairs Minister Franco Frattini on the war in Gaza as "particularly inadequate."

Roberto Calderoli of the Lega Nord (LN, Northern League) and Maurizio Gasparri of Alleanza Nazionale (AN, National Alliance) express their opposition to the suggestion made by Prime Minister Silvio Berlusconi that Ferruccio Fazio, undersecretary of health, and Michela Brambilla, undersecretary of tourism, be "promoted" to ministerial positions.

5 After a meeting with Mayor Letizia Moratti of Milan, Umberto Bossi, the minister of federal reforms, reaffirms his willingness to defend Malpensa airport and his support for Lufthansa as a partner of Alitalia.

7 After meeting with Gianni Letta, secretary to the Council of Ministers, and the top airline officials of the Compagnia Aerea Italiana (CAI), Berlusconi gives his approval for an alliance between Alitalia and Air France-KLM. Bossi, however, claims that "the 
discussion is still open. It is stupid to strike a deal with the French, who will close Malpensa."

The Associazione Nazionale Magistrati (ANM, National Association of Magistrates) "expresses its astonishment and concern" regarding the statements made by Nicola Mancino, the vice-president of the Consiglio Superiore della Magistratura (CSM, Governing Council of the Judiciary). Suggesting not only to modify the composition of the CSM, Mancino wants to reassert the legal principle of fiduciary responsibility. "Astonishment and bitterness" concerning these same statements are also expressed by 13 judiciaries of the CSM.

9 The LN proposes an amendment to the "anti-crisis" decree that would require non-EU citizens to pay 50 euros in order to obtain or renew their residence permits. Furthermore, if non-EU citizens were to open a new business, they would have to provide proof of having 10 million euros at their disposal. The PD calls the amendment racist. Gianfranco Fini (AN), the president of the Chamber of Deputies and co-founder of the Popolo della Libertà (PdL, People of Liberty), is also opposed.

10 In an open letter to the Corriere della Sera, Fini indicates six pillars of reform for the judicial branch. Veltroni welcomes this initiative, but clearly underlines that "what Fini has claimed is very different from Berlusconi's behavior.” The government expresses its negative assessment of the amendment regarding taxes for immigrants.

Berlusconi is in Sardinia, campaigning for the regional elections. He attacks the candidate of the center-left, Renato Soru, for having "enacted only dirigist laws."

11 In an open letter to the Corriere della Sera, members of the PdL declare that they will leave the RAI Vigilance Commission and will not return until Riccardo Villari (PD) resigns as its president.

Moratti attacks the government for the choices that have been made in the Malpensa and Expo affair.

Berlusconi reaffirms his wish to reform the judiciary branch, "with or without the PD," and denies ever to have had the intention of prohibiting wiretapping as a means to fight crimes such as corruption.

12 The leaders of CAI accept an alliance with Air France-KLM.

13 Fini criticizes the government for having granted its confidence to the "anti-crisis" decree.

The government engages in a debate on the taxation of the residence permit, which Minister of the Interior Roberto Maroni would like to introduce. 
Veltroni demands that the internal squabbles within the PD be put to an end, claiming that "sooner or later this auto-destructive instinct ought to stop."

14 Diplomatic confrontation with Brazil, which refuses to permit the extradition of Cesare Battisti, who was condemned in Italy for the crimes committed by the Communist Proletarian Army in the 1970s.

The Conferenza Episcopale Italiana (CEI, Italian Episcopal Conference) states that "the taxation of the residence permit is an unacceptable charge on a group that is little protected."

Giuseppe Setola, leader of the Casalesi clan in the Camorra crime organization, is captured.

15 The Bank of Italy estimates that the gross domestic product (GDP) will drop by 2 percent in 2009. Tremonti tones down this estimation as "simply a rough guess."

Tremonti apologizes for the hardships endured by some beneficiaries of the "social card," which is intended to provide discounts for needy people.

In Naples, Cristiano Di Pietro, the son of the leader of the IdV, is investigated.

16 Fini declares that the episode of RAI 2's television talk show AnnoZero (hosted by journalist Michele Santoro) on the war in Gaza is "indecent." The Israeli ambassador to Italy, Gideon Meir, protests as well.

17 President Napolitano's letter to the Brazilian president, Luiz Inácio Lula da Silva, expresses "astonishment and regret" concerning the refusal to extradite Battisti.

18 During an official visit to the United Arab Emirates, Fini confirms that prayers in Italian mosques will be conducted in Italian in order to avoid the risk that hatred and violence would otherwise escalate.

19 Villari declares his willingness to resign as president of the RAI Vigilance Commission after having "exhausted the obligations of the commission," among which is the nomination of the Administrative Council of the RAI. After the resignation of 35 members out of 40, the commission is "paralyzed," in the words of Renato Schifani, the president of the Senate and a prominent member of the PdL.

The CSM suspends Luigi Apicella as public prosecutor of Salerno. Apicella had clashed with the Catanzaro public prosecution offices during the "Why Not" investigation.

20 When the nursing home in Udine declares that it cannot accommodate Eluana Englaro by interrupting her feeding, the president 
of the Piedmont region, Mercedes Bresso, states: "Piedmont will be willing to accommodate Eluana in its public institutions, because the private ones are being held hostage by the minister." Cardinal Severino Poletto speaks of "euthanasia."

Referring to estimates of a decline in GDP, Berlusconi asserts: "GDP at a negative 2 percent? If that were the case, we would return to the same situation as two years ago, which does not strike me as all that bad."

21 The presidents of the Senate and of the Chamber of Deputies dissolve the RAI Vigilance Commission, from which 37 members have resigned.

22 Berlusconi announces a bailout plan for Fiat.

A deal is struck between the government, the Confederazione Italiana Sindicati dei Lavoratori (CISL, Italian Confederation of Workers' Unions), the Unione Italiana del Lavoro (UIL, Italian Union of Labor), and the Unione Generale del Lavoro (UGL, General Union of Labor), regarding the reform of the contractual model in the public sector. The Confederazione Generale Italiana del Lavoro (CGIL, Italian General Confederation of Labor) does not sign.

In the Senate, the bill on federalism receives its first "yes" vote. The PD abstains, for which it is thanked by Bossi.

23 CGIL requests a referendum on the deal that had been struck between the government and the other unions.

24 In Lampedusa, 1,300 immigrants escape from the center of first reception and return after two hours, following a demonstration in front of the town hall.

Debate erupts on the home detention of a young man who had been arrested for sexual violence in Rome.

25 Controversy arises with regard to Berlusconi's statement that, in order to put an end to the numerous acts of sexual violence, "we should have as many soldiers as beautiful girls."

Berlusconi comments on the latest developments in the socalled Genchi affair (named after Gioacchino Genchi, the head of the police who, on behalf of the judiciary, has repeatedly engaged in wiretapping), as handled by the Security Committee in Parliament. It would be "the biggest scandal of the Republic. One person has put 350,000 people under scrutiny."

Veltroni defends the reform of labor contracts, adding, however, that "a solution ought to be found that also takes into account CGIL." CISL and UIL express their opposition to a referendum on the reform.

26 Veltroni attacks Berlusconi: "Instead of worrying about the crisis like other European leaders," Berlusconi campaigns in Sardinia. 
27 The Italian government recalls its ambassador to Brazil in protest against that country's decision to grant Battisti refugee status.

28 Confindustria warns that " 300,000 jobs are at risk."

Di Pietro criticizes Napolitano ("respectfully"), claiming that he sometimes does not act like a "referee." Negative reactions from the presidents of the upper and lower houses and from those allied with Veltroni.

There is an agreement between the PdL and the PD to modify the electoral system for the European elections (4 percent threshold, maintaining preference votes).

29 At the World Economic Forum in Davos, Tremonti asserts that "welfare and pensions ought to be reformed."

Small parties protest against the electoral law reform ("a scam").

After long discussions, the government reaches an agreement on wiretapping. The new regulations allow it only in the case of "serious suspicion of crime" and for 45 days, which can be extended by an additional 15 days. The PD and the IdV are opposed. According to Luca Palamara, the president of the ANM, "the investigating magistrates run the risk of being shut down."

\section{February}

1 In the town of Nettuno (in the province of Rome), a homeless immigrant is beaten and burned. Three Italians are arrested.

2 Napolitano addresses the issue: "The responsibilities are of an institutional, cultural, and educational nature because they are aimed at putting a halt to any manifestation and risk of xenophobia, racism, and violence.”

Referring to Giuseppe ("Beppe") Pisanu (PdL), who had urged the government to abstain from "conversations that are held in the taprooms of Padania," Maroni finds that these "accusations stem from the do-gooders of the old days. I think that in order to combat illegal immigration one ought to be mean, determined, and affirm the severity of law."

3 Napolitano requests a law on "biological testaments" or "living wills" - that is, a document affirming one's willingness to undergo euthanasia.

Eluana Englaro arrives at the hospital La Quiete di Udine, where her feeding will be suspended.

The lower house approves the new electoral law concerning the European elections with a threshold of 4 percent. Small parties protest. 
4 Regarding the bill on security, the government is defeated over an amendment submitted by the PD: the duration of immigrants' stay in an identification center remains at 60 days and is not raised to 18 months.

Sergio Zavoli is nominated to be head of the RAI Vigilance Commission.

5 The Senate passes the Maroni security package. Among the new measures introduced are the taxation of the residence permit and, even more controversial, the ability of doctors to report illegal immigrants who come to see them. Veltroni finds these measures "racist."

The government works on a decree that would prevent the suspension of Eluana Englaro's feeding.

Di Pietro addresses an open letter to Napolitano in which he accuses Berlusconi of "recycling the ideas of Germany's National Socialist Party of the 1930s," asking the head of state to intervene in matters such as wiretapping, the nomination of board members of the RAI and the CSM, etc.

6 Napolitano sends a letter to Berlusconi in which he urges the government not to proceed with the decree regarding the Englaro case. The Council of Ministers approves the decree aimed at prohibiting the suspension of feeding nonetheless. The head of state declares that he will not sign the decree. A special Council of Ministers transforms the decree into a bill. Meanwhile, at the hospital La Quiete di Udine, the suspension of feeding for the comatose woman is initiated. Veltroni claims that "Berlusconi deliberately wanted to create an institutional conflict out of political interest."

Pierluigi Bersani announces his candidacy to become secretary of the PD: "Not doing it last time was a mistake."

7 Berlusconi states that the government should have the responsibility to assess decrees and that therefore the Constitution (which was "drafted many years ago in the presence of political forces that looked at the Russian Constitution as a model") ought to be reformed.

Beppino Englaro asks the presidents of the Republic and of the Council of Ministers, "from father to father," to visit his daughter in order "personally and privately to witness her condition."

8 A police investigation of the hospital La Quiete di Udine reveals presumed irregularities regarding the protocol as it is fixed by the judiciary.

In the Senate, the bill to prohibit the suspension of Eluana Englaro's feeding is scrutinized. The PD is divided on the issue. Many Catholics (including Enrico Letta, the deputy secretary of the PD) are tempted to vote in favor of the bill. 
9 The announcement of Eluana Englaro's death unleashes turmoil in the Senate. According to Gaetano Quagliarello (vice-president of the PdL), the woman "was murdered." Anna Finocchiaro (PD) responds with a charge of "political profiteering." Berlusconi asserts that "Napolitano has made a terrible mistake." Gasparri (AN) reaffirms that "this incident will be defined by the signatures that were on the bill and those that were not," a statement described by Fini as "irresponsible."

10 Napolitano urges the police forces to "reflect" upon "the national grief and pain” following Englaro's death.

11 Bossi defends Napolitano against the attacks of his allies ("he is a figure of reassurance") and assures "we will not change the Constitution."

12 In Rome, there is a demonstration by the PD in defense of the Constitution. Former president and Senator-for-Life Oscar Luigi Scalfaro states that "claiming that the spirit of the Constitution is driven by communism is blatant ignorance."

13 Berlusconi is concerned about the drop in GDP ( -0.9 percent).

CGIL organizes a strike against the economic policy of the government.

14 The PD presents its "anti-crisis" plan to its membership and sends it to the government. Fabrizio Cicchitto, head of the PdL in the Chamber of Deputies, describes it as "unachievable proposals."

15 After incidents of sexual violence, the government announces the launch of a decree in anticipation of certain measures of the security bill, which is still being discussed in the Senate.

16 Ugo Cappellacci (PdL) defeats Renato Soru (PD) and becomes the new president of Sardinia.

17 Veltroni resigns as secretary of the PD.

First degree verdict in the David Mills trial. The English lawyer is condemned for corruption and is sentenced to prison for four and a half years.

The assembly of the CSM formulates a negative assessment of the bill on wiretapping.

18 Veltroni's farewell speech: "Do not demand immediate results from my successor."

There are confrontations between immigrants and the police in Lampedusa.

19 Arturo Parisi requests that primary elections be held in order to choose the new secretary of the PD.

After a meeting with British Prime Minister Gordon Brown, Berlusconi affirms that the nationalization of banks is a possibility. He then clarifies that this "does not apply to Italian banks." 
20 The government approves the "anti-rape" decree. Among the measures, the most controversial one foresees the potential of deploying unarmed ronde (organized civilian patrols), consisting of former policemen and soldiers.

21 With 1,047 out of 1,258 votes, the national assembly of the PD elects Dario Franceschini as its new secretary.

22 Franceschini attacks Berlusconi: "He has a country in mind in which power is increasingly and tacitly concentrated in the hands of a single person. This goes against the Constitution."

23 Napolitano hopes to re-examine the "decisions concerning the budget which are anchored in the logic of undiscriminating cuts."

There is internal division within the PD regarding the living will. Dorina Bianchi, the head of the Health Commission, does not sign the amendments.

24 Meeting between Berlusconi and French President Nicolas Sarkozy results in an agreement to determine the feasibility of building four nuclear power stations in Italy.

Ex-Minister Pisanu (PdL) declares that he will not vote in favor of the bill on living wills.

25 Maurizio Sacconi, the minister of labor, health, and social policy, announces a bill on the regulation of strikes in the transport sector. Among the new measures: preventative balloting and "virtual strike." CGIL protests.

The government announces the so-called Tremonti bondsspecial obligations issued by banks and undersigned by the Treasury-in order to reinforce the patrimonial solidity of institutions providing credit.

Fini urges the government to refrain from a vote of confidence regarding the bill on wiretapping.

26 The reform of wiretapping, an issue that divides the PD, is discussed in the lower house and then postponed until 23-24 March.

First meeting with the new PD secretary. Franceschini, who has reset the "shadow government," presents the heads of the 12 departments of the party.

Pietro Ichino (PD) and seven other senators of both the majority and the opposition request to postpone the living will bill for three months. The request is refused by the heads of the PdL and the PD.

27 The government announces a decree on the regulation of strikes in the transport sector, which does not require parliamentary approval. The opposition criticizes the lack of parliamentary control.

28 Franceschini: "Our first proposal is a monthly unemployment contribution to those who have lost their jobs." 


\section{March}

1 Berlusconi: "The commitments to the Maastricht criteria render the unemployment benefits as put forward by the PD unsustainable. They would cost us 1.5 percent of the GDP."

2 The GDP figures of 2008 show a drop of 1 percent, the worst result since 1975. Stocks plummet around the globe. Milan: -6.02 percent.

Berlusconi meets with Libyan leader Muammar al-Gaddafi and apologizes for Italy's colonial past.

Franceschini reaffirms his proposal on unemployment benefits and invites Berlusconi to repeat his "no" in Parliament.

3 The government presents a draft to the European Union on the reform of pensions. It foresees the gradual increase of the pension age of women who work in public administration, with the aim of arriving at the age of 65 in 2018. CGIL says that this is "unacceptable."

4 According to figures of the Istituto Nazionale Previdenza Sociale (INPS, National Social Insurance Institute), compared to 2008, the redundancy payment has increased by 553 percent. The Bank of Italy's GDP forecast: -2.6 percent in 2009.

Minister of Culture Sandro Bondi proposes to "decouple one of the RAI networks from the Auditel survey system and from advertising."

5 Milan stock drops 5.39 percent.

Frattini finds "unacceptable" the United Nations (UN) document on racism circulated in anticipation of the upcoming Durban Review Conference to be held in Geneva, 20-24 April. He announces Italy's intention to withdraw if "anti-Semitic sentences" are not removed.

6 Presenting new "anti-crisis" measures, Berlusconi declares: "It is a worrisome crisis, but not a tragic one. It is damaging that certain [voices in the] media continue to portray it as inevitable."

7 In order to rejuvenate the economy, Berlusconi announces a "house plan" (piano casa) that would ease regulations for construction and urban planning.

8 Franceschini attacks Berlusconi's "house plan" as "a dangerous plan that would turn the current situation into a cement jungle."

10 Berlusconi aspires to a change of parliamentary rules in order to adapt to "the necessities of a government that wishes to act in the short run. Only the head delegates would vote." Fini: "The proposal will not find support."

11 In order to help the poor, the PD proposes a one-time increase of 2 percent on the income tax of those who earn more than 120,000 
euros annually. Bossi agrees, but there is criticism from the rest of the majority.

12 Berlusconi calls Franceschini "a Catholic-Communist leader."

14 The president of Confindustria, Emma Marcegaglia, asks the government to allocate "real money" in order to combat the crisis.

At an assembly of liberal reformists, Berlusconi assures that, in the PdL, freedom of conscience will always be respected on ethical issues.

15 Berlusconi replies to Marcegaglia: "We have given very real money to the economy up to this day."

In Cernobbio, Berlusconi claims the right to govern by decree, asserting that it is "the only real power I have." He adds: "The head of state has to sign only what is presented to the Parliament."

In an interview on RAI 3's television talk show, Che Tempo Che Fa, Romano Prodi declares: "My executive power could have continued ... but it was made to stop." The former prime minister considers Veltroni's announcement that the PD would "run alone" to be the trigger that provoked the loss of power.

17 Marcegaglia meets with Berlusconi and claims to be satisfied with the government's effort to guarantee 1.3 billion euros for loans to small and medium-sized companies ("this is real money").

18 A letter advanced by Alessandra Mussolini is signed by 101 deputies of the PdL. In it, they ask Berlusconi to modify the bill on security, eliminating the ability of doctors to denounce illegal immigrants.

19 Berlusconi intervenes regarding the "spy doctors" and the ronde, claiming that these measures were implemented as a concession to the LN and declaring that he shares the underlying spirit of the 101 deputies' letter.

Renato Brunetta, the minister of public administration and innovation, describes the students of Onda, who have demonstrated in various schools, as "guerrillas" and says that "they will be treated accordingly."

21 In Rome, the congress concerned with dissolving the AN begins. The party will then be incorporated in the PdL.

Franceschini attacks Berlusconi on his decision to run for the European elections: "A prime minister as a candidate is a scam for the electorate."

22 At the last AN congress, Fini intervenes: "The PdL is not a party of a single person ... It should be open, plural, inclusive-a unitary party without one single mind."

23 Franceschini rejects the "house plan" as being unconstitutional ("the competence to do so lies with the regional authorities"). 
The PD and PdL reach an agreement on the presidency of the RAI: Paolo Garimberti (a journalist of La Repubblica).

24 Napolitano sends an informal note in which he invites Berlusconi to listen to the regions and communes with regard to the "house plan."

With the "yes" vote of the IdV, the abstention of the PD, and the "no" vote of the Union of the Center (UdC), the lower house approves the bill on federalism, which is sent to the upper house for final approval.

25 Following pressure from the regions, the government declares that the "house plan" will not be introduced via decree. Instead, it will be handled through a technical round with local entities.

26 The bill on living wills is approved by the Senate and passed to the lower house. Discussion ensues about the circumstances under which doctors are not obliged to take into account a patient's wish as expressed in a living will. Representatives of the PD threaten to subject the bill to a referendum.

Berlusconi inaugurates the regional incinerator at Acerra: "The state is here. The left has lost because it has opposed everything."

27 The congress aimed at founding the PdL starts. Berlusconi announces: "We are the party of the Italians. The polls give us 43 percent."

28 At the PdL congress, Fini, who asks the party to formulate a stance on the referendum on electoral reform, wishes "a great constituent season" and criticizes the bill on living wills that had been approved by the Senate.

29 At the PdL congress, Berlusconi, the new party's president, indicates his objective to reinforce the powers of the prime minister ("they are almost non-existent") and to "modernize the architecture of the state. We will proceed nonetheless," even without the opposition.

On the referendum, Bossi tones down the declarations made by Fini.

30 US President Barack Obama praises Fiat ("the current management has been able to realize an impressive turning point") and the agreement that it is about to reach with Chrysler.

\section{April}

1 The Constitutional Court rules that some articles of Law No. 40 (on artificial insemination) are illegitimate, among which are those that limit the number of implantable embryos to three. 
The government presents the terms of the agreement reached with the regions on the "house plan."

2 Fini states that Law No. 40 "has defended women's rights."

4 Rome: according to the organizers, a CGIL demonstration draws between 700,000 and 2 million participants, according to the police, 200,000. CGIL's leader, Guglielmo Epifani, says that there is "too much discrepancy between what the government has to do and what it does not do."

5 Attacking Di Pietro, who, like Berlusconi, has announced his candidacy for the European elections, Franceschini's comment is "wasted votes."

6 Earthquake in Abruzzo. Visiting the affected areas, Berlusconi declares: "The state is here. Nobody will be left alone." Representatives of the IdV, the Radicals, and the Rifondazione Comunista (RC, Communist Refoundation) criticize the head of the civilian protection agency, Guido Bertolaso, for not having listened to scientist Giampaolo Giuliani, who had warned that an earthquake was about to take place.

7 The public prosecutor of L'Aquila opens an investigation in order to determine possible negligence for the damages caused by the earthquake.

8 The lower house rejects the provision in the security bill that called for a stay of six months for illegal immigrants in centers of identification and expulsion. Maroni: "I am furious." The provision allowing for ronde is removed. With these changes, the opposition now agrees on the bill.

9 Napolitano visits the areas affected by the earthquake: "Laws were not carried out ... there ought to be an introspection removed from political considerations."

In order to obtain funds for the reconstruction of Abruzzo, Berlusconi proposes organizing the European elections and the electoral reform referendum on the same dates ( 6 and 7 June) - a proposal that had initially been launched by the PD and the Referendum Committee and was subsequently rejected by Berlusconi.

11 Tremonti launches a proposal to incorporate the reconstruction of Abruzzo among the beneficiaries of the 5 percent tax exemption.

The LN staunchly opposes the proposal of holding European elections on the referendum date.

12 Non-profit organizations express their opposition to Tremonti's idea of the 5 percent tax exemption.

14 Maroni declares that 12 billion euros will be needed to reconstruct Abruzzo. 
15 Agreement is reached between the PdL and the LN on the date of the referendum: 21 June, in conjunction with the second count of the administrative elections. Fini criticizes it as "a waste."

Discussion ensues on how to fund the reconstruction of Abruzzo. Ideas include a one-time tax on high incomes and a 5 percent increase in the gasoline tax.

16 Berlusconi admits that not having agreed to organize the European elections and the referendum simultaneously was driven by the threat that the LN might bring down the government. The possibility arises that the referendum will be postponed another year.

17 Letter from Napolitano to Berlusconi, Tremonti, and the presidents of both legislative houses: enough with the "omnibus decree laws" ("they limit the prerogatives" of the head of state).

With regard to the UN's Durban Review Conference on racism, Frattini confirms Italy's "no."

18 Berlusconi promises that no new taxes will be introduced for the reconstruction of Abruzzo and declares that he will cast his vote during the referendum on electoral reform.

19 For "humanitarian reasons," the government authorizes a Turkish freighter with 140 immigrants to dock at Porto Empedocles and criticizes Malta for having rejected the refugees, in spite of the European Union's (EU) request not to do so, referring to Malta's decision as "incorrect and censurable."

21 Berlusconi declares that he will participate in the 25 April celebrations commemorating Italy's liberation by Allied forces "because this event does not belong to just one side."

22 Speaking at Turin's Biennale Democrazia (Festival of Democracy), Napolitano declares that the Constitution "is not just a result of the war" and that "one should not simplify the system and restrict certain rights in the name of the government's duty."

The International Monetary Fund's (IMF) GDP growth forecast: -4.4 percent in 2009.

23 The Council of Ministers meets in L'Aquila. Eight billion euros are allocated for the reconstruction of Abruzzo. The government announces that July's G8 summit, initially planned to be held in La Maddalena, will now take place in L'Aquila.

24 European Commissioner Günther Verheugen criticizes Fiat for taking interest in the German Opel: "Fiat is in debt. Where will it find the money?" Fiat's chief executive, Sergio Marchionne, and Ministers Frattini and Tremonti react harshly.

25 Berlusconi takes part in the 25 April celebrations in Onna, Abruzzo. He declares to be "part of those who have fought for our freedom" 
and praises the founders-among whom were Palmiro Togliatti and the Communists-for having "set aside their differences" and for having "channeled them toward one objective."

28 Berlusconi announces that he will vote "yes" during the referendum on electoral reform.

In an open letter to a news agency, Veronica Lario, Berlusconi's spouse, responds to allegations that the PdL intends to put various showgirls on its European parliamentary electoral list, denouncing the party's plan as "shameless rubbish" for the "entertainment of the Emperor."

29 In the Senate, the bill on fiscal federalism passes. The IdV votes "yes," the PD abstains, and the UdC votes "no."

Maroni threatens to bring down the government if the referendem on electoral reform were a success.

The "Noemi case" becomes public knowledge. Noemi Letizia is the 18-year-old whose birthday party Berlusconi attended and who claims to call him "Papi."

30 The Fiat-Chrysler agreement is signed.

\section{May}

3 The Council of Ministers sets 21 June as the official date of the referendum on electoral reform.

Lario announces her intention to divorce Berlusconi. His reaction: "I am outraged. I know who stirred this up."

In Afghanistan, Italian soldiers shoot at a passenger car, killing a 12-year-old Afghan girl and wounding three family members.

4 Interview with Franceschini in Corriere della Sera: "Berlusconi's style resembles that of certain former Soviet Republics in Central Asia," where "the personal power of the head of state is intertwined with the power of the state and its economic powers."

Fini foresees "problems of unconstitutionality" regarding the regulation on "spies" in the security package: the regulation requires a residence permit for those who request a public service. Maroni, however, defends the regulation.

5 On RAI 1's political talk show, Porta a Porta, Berlusconi speaks about his divorce, claiming that his spouse has made an error of judgment and has fallen into the "trap of the left and its press." The daily paper L'Avvenire editorializes on the matter, asking the prime minister to show more "sobriety."

After the doubts expressed by Fini, the regulation on "spies" is eliminated from the security bill. 
6 Upon the LN's request, the Council of Ministers decides to grant its confidence in the security bill.

Conflicts arise about the funds for the reconstruction of the areas that were hit by the earthquake. L'Aquila's mayor, Massimo Cialente, declares that "Berlusconi will have to take the responsibility of informing the Italian citizens that this reconstruction will require a sweeping tax."

7 A boat with immigrants, adrift in the canal of Sicily, is taken back to Libya by the Italian coast guard. For Maroni, this represents a "historical turning point."

Conflicts about the suggestion made by Matteo Salvini, a lawyer from Milan, who wants to reserve seats in Milan's public transit system for Milanese people.

8 The government announces a new undersecretary of tourism, Michela Brambilla, and five new vice-ministers.

9 At the presidential palace, in remembrance of the victims of terrorism and bloodshed, the widows of police commissioner Luigi Calabresi and anarchist Giuseppe Pinelli meet.

Referring to the boat that was sent back to Libya, Berlusconi declares that Italy "has not violated international agreements" and that the government does not want a "multi-ethnic Italy," like the left has in mind.

10 Criticism from the CEI about sending back the immigrants.

11 Fini intervenes in the boat affair: "Sending back those immigrants did not violate international law, but Italy has an obligation to find out whether-of those who were sent back—-some have the right to request asylum."

12 The UN Refugee Agency warns the Italian government that sending back immigrants may put the asylum law at risk.

14 The lower house approves the security package (after the government had already granted its confidence), which introduces the notions of underground crimes and civilian patrols. Harsh words from Franceschini: "These civilian patrols remind us of the 'Black Shirts."”

At the conference of the European Center of Foundations, Napolitano declares: "In Italy a public rhetoric is spreading that does not hesitate to incorporate elements of intolerance or xenophobia."

15 The Istituto Nazionale de Statistica (ISTAT, National Statistical Institute) releases figures: during the first three months of 2009, Italy’s GDP fell 5.9 percent-its worst performance since 1980.

16 In Turin, during a demonstration of workers at Fiat, the stage of Gianni Rinaldini, leader of the Federazione Impiegati Operai 
Metallurgici (FIOM, Federation of Metallurgical Employees), is assaulted by the Confederazione dei Comitati di Base (COBAS, Confederation of Base Committees), a trade union center.

Defense Minister Ignazio La Russa attacks Laura Boldrini, the spokesperson in Italy of the United Nations High Commissioner for Refugees (UNHCR), who had opposed the act of "sending back immigrants." La Russa claims that the UNHCR is "an entirely worthless organization."

18 In Turin, confrontations take place between police and students who are protesting against the summit held by the rectors of more than 200 universities - the "G8 of rectors."

The UNHCR characterizes La Russa's statement as "unacceptable attacks." Maroni tries to sooth tensions by describing the UNHCR's role as "fundamental."

19 Justification for the verdict imprisoning David Mills for four and a half years. To the judges of Milan, the English lawyer lied "in order to grant Berlusconi and the group Fininvest immunity from allegations." Berlusconi swears that he is innocent and declares that the verdict stems from "political hatred and envy." Franceschini asks the prime minister to reject the socalled Alfano law (which suspends penal prosecution of those who are in a high executive position) and to subject himself to the judiciary.

Speaking of bioethics, Fini declares that "the Parliament must generate laws that do not stem from religious precepts."

The minister of economic development, Claudio Scajola, intervenes in the possible alliance between Fiat and Opel that is being proposed by Marchionne and his German counterparts. The trade unions have already expressed their concerns, fearing for employment. Scajola: "For the government, it is imperative to keep five Fiat plants in Italy."

20 Appointments at the RAI: Augusto Minzolini at TG1, and Mauro Mazza director of RAI 1. Division within the RAI board of directors (the disagreeing board members leave the meeting to express their discontent), and criticism from opposition parties.

21 At the Confindustria assembly, Berlusconi attacks the Milanese judges ("extremists of the left") and declares that it is necessary to reduce the number of parliamentarians to 100: "The plethora of assemblies are useless and counter-productive.”

Marcegaglia invites Berlusconi to use the consensus that he now enjoys in order to push "the reforms" through.

22 Fiat announces that its offer for Opel foresees a reduction of the workforce in Europe of less than 10 million units. The heads of 
the regions Assia and Renania declare their preference for the offer made by the Austrian-Canadian group Magna.

23 Berlusconi speaks once again of the reduction of the number of parliamentarians: "I am really thinking of a bill initiated by the people in order to bring the number down from 300 to 150 ." The head of the PD writes to the IdV and the UdC to propose a common front against the initiative, but this suggestion is rejected.

24 Franceschini invites Berlusconi to go to the Parliament in order to shed some light on the "Noemi case." While the press continues to ask questions and can demonstrate that Berlusconi has been lying, the prime minister "remains silent." Paolo Bonaiuti, the government's spokesman, refers to this request as "the left clinging to gossip."

25 The president of Sicily, Raffaele Lombardo of the Movimento per l'Autonomia (MpA, Movement for Autonomy), readjusts his inner circle because of insurmountable differences with his allies, the PdL and the UdC. He promises a new political constellation within 48 hours: "It will be composed of political forces and external personalities."

27 Franceschini attacks Berlusconi regarding the scandals surrounding his private life: "Would you let this man educate your children? He who governs the country ought to set a good example." The prime minister and his children react harshly.

28 With regard to the "Noemi case," Berlusconi declares: "I have never had any spicy relationships with underage women. I have sworn this on my children. If something like this would have happened, I would have immediately resigned."

At the assembly of the Confesercenti, the confederation of commercial and tourism shopkeepers, the prime minister attacks the judiciary ("internally made up by some subversive lumps").

29 The governor of the Bank of Italy, Mario Draghi, invites the government to engage in structural reforms in order to favor growth and to urge the banks to "follow the example of those bankers who financed the reconstruction and growth of the 1950s and 1960s."

In Sicily, Lombardo describes his new government as one "of autonomy made up by free men who detach themselves from the dictatorship of the central parties." The UdC of Salvatore Cuffaro (who asks for Lombardo's resignation and new elections) is excluded, while the PD is torn between the representatives close to Gianfranco Miccichè (in favor) and those close to Schifani (opposed).

30 Following the charges put forward by Berlusconi's lawyer, the attorney of Rome confiscates the photographs taken at Villa Certosa, where the prime minister hosted a party that was attended by numerous young girls, including Noemi Letizia. 
The German government chooses Magna to acquire control over Opel. Franceschini criticizes the Italian government as "absentminded."

31 The opposition asks Berlusconi to clarify in Parliament the use of governmental flights. Some Sardinian photographs show that Berlusconi has hosted people on those flights who are not part of the government, such as the singer Mariano Apicella.

\section{June}

2 Napolitano addresses the political parties: "I hope that however the elections will turn out, everyone will understand the necessity of more well-judged and moderate behavior ... The feeling of unity is spreading more among the Italian people themselves than what one might perceive in certain political domains."

3 The attorney of Rome registers Berlusconi as being investigated for "abuse of power," due to his use of governmental flights. The prime minister states that he is "calm." He adds: "This is just pettiness. There is no additional cost to take on more passengers. It is a question of practicality."

7 The European elections end. Turnout is 65.1 percent. The results show seats gained for the PdL (35.3 percent of the vote), the PD (26.1 percent), the LN (10.2 percent), the IdV ( 8.0 percent), the UdC (6.5 percent), and the Südtiroler Volkspartei (0.5 percent). The radical left, which presented itself in two different lists, does not pass the 4 percent threshold: RC-Partito dei Comunisti Italiani (PdCI, Party of Italian Communists) (3.4 percent) and Sinistra e Libertà (SL, Left and Liberty) (3.1 percent).

8 The administrative elections are a victory for the center-right: out of 62 provinces (of which initially 50 were governed by the center-left and 9 by the center-right, with 3 newly created), 26 go to the center-right and 14 to the center-left (with a second round of votes for the remaining 22). In 30 communes, where initially there was a ratio of 25 to 5 in favor of the center-left, there is now a ratio of 9 to 5 in favor of the center-right (with 16 communes up for a second round of voting).

Berlusconi has dinner with his LN allies. The prime minister refuses to support the referendum on electoral reform in return for the LN's support for candidates of the PdL during the second round of voting.

9 Fini distances himself from the statements made by Berlusconi about the referendum on electoral reform: "I am going to vote 
and will do so with conviction." According to the PD, the prime minister is being "held hostage by the LN."

10 Official visit in Italy by Gaddafi, who praises Italy for "having apologized for its fascism." Conflicts arise between the political parties regarding the possibility of Gaddafi's speech being made in the Senate.

11 With regard to the US bombing of Libya, which was approved by Ronald Reagan in 1986, Gaddafi compares the United States ("a state with rules") to Osama bin Laden ("an outlaw").

The lower house approves the bill that limits wiretapping. Protest by the opposition (among whom there are 17 "sharpshooters").

12 Fini cancels a meeting in the lower house with Gaddafi because the Libyan leader arrived late. Nonetheless, Fini distributes the text of Gaddafi's speech, distancing himself from the Libyan leader's statements about the United States and terrorism, and hoping that an Italian delegation was able to observe how immigrants in Libyan camps are taken in.

13 At an assembly of the Young Industrialists, Berlusconi claims that the recent scandals are "a slander." He refers to the "Noemi case," David Mills, and the use of governmental flights as part of a "subversive project" to provoke the collapse of his government, which would then be replaced by that of "someone who was not elected by the Italians."

14 Controversial statements made by the former prime minister and minister of foreign affairs, Massimo D'Alema (In Mezz'ora, RAI 3), who claims that the majority of Italian citizens-being guided by a "leader cut in half," that is, Berlusconi-are "upset."

15 Washington, DC: meeting between Berlusconi and Obama. The US appreciates Italy's decision to send 600 additional troops to Afghanistan. Berlusconi also announces that Italy will take three prisoners from the Guantanamo detention facility when it closes.

16 The Rome public prosecutor files the investigation into the use of governmental flights by Berlusconi.

17 Political conflicts about the indiscretion of Corriere della Sera in exposing wiretapped telephone conversations, according to which money would have been transferred to some girls in order to take part in Berlusconi's parties at his residences (Palazzo Grazioli and Villa Certosa). The public prosecutor of Bari is presumably investigating crimes of prostitution. Berlusconi: "It is the usual rubbish, aimed at destroying me."

The PdL attacks D'Alema, in light of his recent statements. D'Alema: "My statements reflected a political opinion. I do not know what the public prosecutor of Bari intends." 
18 Political conflicts on the matter continue. Berlusconi: "The government is stable. There are no uprisings." Fini denounces the "frequent use of mutual delegitimization," which renders it "difficult to assess the mentality of democracy as mature." The opposition asks the prime minister to clarify the facts. According to Di Pietro, Berlusconi's "private issues ... reveal a real threat: the ability to blackmail a key figure of the government."

During the meeting at the Palazzo Chigi between Fiat, the government, and the unions, Marchionne assures that the Italian plants will not close (although there will be some cutbacks). The government initiates three round-tables with the regions, unions, and firms.

20 After the low turnout during the referendum on electoral reform is made clear, the proponents blame Minister of the Interior Maroni: "In many cases the consultation has been boycotted."

22 The referendum on electoral reform does not attain the necessary quorum (turnout is lower than 24 percent). The LN is satisfied. Proponents criticize public television for a lack of attention to the matter. Franceschini declares that "the electoral law is not suitable. A new one ought to be made."

The second round of voting results in a victory for the PD in the communal elections of Bologna, Firenze, and Padova, while the PdL retakes the province of Milan and conquers the commune of Prato for the first time. The electoral battle thus results in an increase in power for the center-right, from 9 to 34 in the provinces and from 5 to 14 in the communes.

23 The secretary of the PD decides that the party congress will be held in October. On his Web site, Bersani announces his candidacy for the position of secretary.

24 Franceschini also announces his candidacy for the position of secretary of the PD: "I cannot give the party back to those who were here before me."

25 Discussion about the GDP between Draghi ("it will fall by 5 percent") and Tremonti ("the proliferation of forecasts these days is just a way of hurting the people, by spreading insecurity").

26 Controversial statement made by Berlusconi. Referring to those who speak of the crisis, he declares: "We ought to silence those people who speak of the crisis and destroy the trust of our citizens."

L'Espresso publishes an article about the dinner between Berlusconi and two judges of the Constitutional Court. The article is controversial because the Constitutional Court is about to discuss the Alfano law. 
27 The government launches the "anti-crisis" decree: firms are exempted from taxes on profits that have been reinvested. Families will have to save on energy and on health care.

28 In an interview (In Mezz'ora, RAI 3), Tremonti denies rumors about a "technical government" that would replace Berlusconi ("it wouldn't last as long as a yogurt").

29 During a press conference, Berlusconi refers to the possibility of a technical government as all nonsense, the invention of some newspapers, and affirms that his is "the most stable government of the West."

In light of the upcoming G8 summit, Napolitano asks the parties to come to a "cease-fire."

\section{July}

1 In an open letter, Luigi Mazzella, one of the judges of the Constitutional Court who was mentioned in the article published by L'Espresso, addresses his invitation to Berlusconi ("Dear Silvio, this was not the first time, and it will not be the last time that I invite you for dinner."). Di Pietro demands Mazzella's resignation.

Bersani announces his candidacy for secretary of the PD. He asserts that the regional elections of 2010 render it necessary to overcome the temptation of self-sufficiency and "to experiment with large alliances of the center-left." Among his supporters are Letta, D’Alema, and Rosy Bindi.

2 With a vote of confidence in the Senate, the security package, which introduces the crime of secrecy and institutionalizes civilian patrols, is approved. The PD, IdV, and UdC are opposed. The Vatican expresses harsh criticism.

3 Maroni responds to the criticism of the Vatican and the CEI regarding the security package, describing it as "the usual liturgy."

4 Vicenza: confrontations with the police during demonstrations against the United States.

Following the objections raised by the Quirinal Palace, the minister of justice, Angelino Alfano, declares that the bill on wiretapping "is not unchangeable."

Ignazio Marino runs for secretary of the PD. Senator Francesco Rutelli supports the candidacy of Franceschini.

5 Undersecretary Carlo Giovanardi suggests regulating the immigrants in Italy who do not have a residence permit but are employed (referring especially to caregivers). Maroni and Calderoli are staunchly opposed. 
7 On the eve of the G8 summit, a controversial article in The Guardian predicts the expulsion of Italy from the G8 and foresees Spain being substituted in its place. Berlusconi calls it a "colossal mistake by a tiny newspaper." The New York Times accuses Italy of "negligence" in organizing the meeting.

8 At the G8 conference in L'Aquila, in contrast to the statement made by the New York Times (which, according to some, reflected the opinion of the US administration), Obama praises "the splendid work this host country has done for the summit."

10 A draft agreement of the majority on the regulation of half a million caregivers is created.

During the press conference concluding the G8, Berlusconi evaluates the summit positively, claiming to be "moved and impressed by the esteemed leaders of the world."

12 Satirist Beppe Grillo announces his candidacy for the primary elections of the PD ("ever since Enrico Berlinguer passed away, the left has been lacking proposals, courage, and ideas"). Negative reactions from the top of the party, which also raises statutory objections regarding the possibility of accepting his candidacy.

14 In Afghanistan, an Italian soldier is killed.

The commission of the PD denies Grillo his candidacy ("he encourages a political movement that is hostile to the party").

15 Napolitano signs the security package into law, but writes a letter to the government and the presidents of both houses in which he expresses "perplexity and concern" for certain provisions, which ought to be reflected upon. The government: "We will take that into account." Di Pietro attacks Napolitano: "He should have sent it back to the Parliament."

The CSM finds the bill on the reform of the criminal law, as it was presented in March by the government and discussed by the Commission of Justice in the Senate, to be "unconstitutional." According to Quagliarello, it "violates the prerogative of the Parliament."

The government announces the Documento di Programmazione Economica e Finanziaria (Document for Economic and Financial Planning) (DPEF) for 2010-2013. The "fiscal shield," which favors the repatriation of capital, is contested by the opposition.

16 Fini remarks that Napolitano's letter contains "politically incisive comments."

Nicola Mancino, vice-president of the CSM, puts the assessment of "unconstitutionality" of the criminal law in perspective. It is not an "absolute rejection" but a "constructive opinion, intended to stimulate the debate." 
19 On the anniversary of the death of magistrate Paolo Borsellino (killed by a Mafia car bomb in 1992), the family affirms that "the state is absent."

20 Napolitano deems it "opportune" to push back the bill on wiretapping until September: "We ought to find common ground for the rules of conduct."

The Web site of the group La Repubblica-L'Espresso publishes extracts from conversations between Berlusconi and the escort Patrizia D’Addario. Niccolò Ghedini, Berlusconi’s lawyer: “This is entirely unreal."

21 Increasing discussion in the Senate on the motions regarding Berlusconi's "personal behavior." According to Luigi Zanda (PD), "the latest remnants of published conversations" reveal "a problem of national security."

22 Berlusconi, referring to the recent polemics: "There are many pretty girls. I am not a saint, as you have all understood. Let us hope that La Repubblica understands this as well."

Di Pietro writes to Napolitano, inviting him to use "the scimitar" against the bill on wiretapping after having used the "velvet glove" for the Alfano law and the security bill.

23 Regarding the "anti-crisis" decree, which is being discussed in the lower house, Fini asks for the removal of provisions that have not been discussed in the commission: "The binomial maximal-trust amendment emphasizes the difficult relationship between the government and Parliament" and "does not allow the complete unfolding of the prerogatives of Parliament."

24 The lower house grants its confidence in the amendment to the "anti-crisis" decree. The MpA leaves the room out of discontent for the measures undertaken for the South.

The Council of Ministers decides on the compulsory administration of health in Campania and Molise. It is "a necessary act," according to Sacconi, so that the 2009 maneuvers of the re-entrance of deficits of the two regions do not seem "guaranteed."

25 After two attacks in Afghanistan during which three Italian soldiers are injured, Bossi declares, "I would take them all home."

26 After various squabbles with delegates of his party (including Miccichè's threat to leave the $\mathrm{PdL}$ ) and disagreements with the MpA regarding the "southern question," Berlusconi intervenes, speaking of an "innovative plan" for the relaunch of the South and attacking the personalismo that would lie underneath claims to the contrary.

27 After the statement made by Bossi about Afghanistan, the heads of the LN, Federico Bricolo and Roberto Cota, declare that "the 
Northern League has always supported the efforts made by the government and will continue to do so in this case as well."

28 The lower house approves the "anti-crisis" decree, including the "fiscal shield" and aid for small enterprises. The deputies of the MpA do not cast their votes, due to the conflicts related to the funds for the South. The government announces its intention to rectify certain measures with a second decree, after the final approval in the Senate.

Controversy about the declarations made by the LN that it is necessary to have a "test in dialect for teachers. They need to know the traditions of the region in which they aspire to teach."

29 Napolitano informs the government that he will sign the "anticrisis" decree only if the prospective changes are contextual and not postponed until September.

Both houses approve the DPEF for 2010-2013.

30 Berlusconi intervenes regarding the possible creation of a long-discussed "party of the South," defining it as an "unacceptable hypothesis" because "those joining it will be forced to leave the PdL." He also announces a freeze on 4 billion euros of the Fondo Aree Sottoutilizzate (FAS, Fund for Underdeveloped Areas) in Sicily.

In Bari, there is an investigation of policemen affiliated with center-left parties regarding alleged illegal funding of outsourcing.

The Agenzia Italiana del Farmaco (AIFA, Italian Medication Agency) approves the RU-486, an abortion pill. Bishop Elio Sgreccia (former director of the Pontifical Academy for Life) declares that "whoever uses and administers it will be ex-communicated."

31 ISTAT estimates that inflation was at zero in July, the lowest level since September 1959.

\section{August}

1 The Senate approves the "anti-crisis" decree. The Council of Ministers approves the rectifying decree. Conflicts break out concerning the taxation of capital gains and the revaluation of the gold reserves of the Bank of Italy.

Grillo announces the formation of a party for the regional elections of 2010, the National Liberation Movement.

Veltroni presents a conflict of interests bill.

2 In response to Scajola's suggestion (in an interview with Corriere della Sera) to extend the legalization foreseen for caregivers to other sectors, Calderoli, the minister of legislative simplification, comments: "This is out of the question." 
3 After Berlusconi assures that the regulation of gold reserves in the Bank of Italy will hold only when both the European Central Bank (ECB) and the Bank of Italy allow for it, Napolitano signs the bill modifying the "anti-crisis" decree.

The Associazione Bancaria Italiana (ABI, Italian Banking Association) and the Entrepreneurial Association sign an agreement on the so-called moratorium of debt for small enterprises. Positive comments from Marcegaglia and Tremonti.

5 The secretary of the CEI, Mariano Crociata, declares that "philandering is a serious act" and speaks of the "disdain of indecency." Although he does not explicitly mention Berlusconi, his words are interpreted by all as referring to the prime minister's behavior.

6 After a meeting with the government, representatives of the oil companies refuse to lower the price of gas once again.

7 In a press conference, Berlusconi evaluates the first 14 months of his fourth government, claiming that the list of accomplishments is "so long that reading it would make anyone feel tired." He also criticizes the mass media, especially RAI 3 ("the only television channel in the world that uses the money it receives from the people to attack the government").

Nichi Vendola, president of the Apulia region, attacks the public prosecutor of Bari, who is investigating the recent scandals in Puglia: "His investigation is turning into an unfortunate tool of political campaigning, aimed at damaging me."

8 Conflicts between Fini and Bossi. Commemorating the anniversary of the 1956 Marcinelle tragedy (the Belgium mine collapse that killed over 200 workers, most of whom were Italian immigrants), Fini affirms that "we need to respect immigrants without documents. People used to emigrate even from the North." Bossi replies: "We used to emigrate in order to work, not in order to kill."

9 Berlusconi opens up to the request of the LN to have "salary clusters": "It is correct to link remunerations to the cost of living and the territory."

10 Confindustria, the unions, and the opposition express their disapproval of the "salary clusters."

14 Declarations by Bossi about the candidacies for the next regional elections (Giancarlo Galan and Roberto Formigoni are "absolutely not okay"), about Expo 2015 ("a demonstration that has lost its importance"), and about a possible alliance with the UdC ("let them be-they are just annoying").

16 In Ponte di Legno, Bossi attacks the national anthem, "Mameli's Hymn" ("nobody knows it"), and presents his bill on the teaching of dialects in schools. 
20 Bossi addresses the candidacies for the regional elections once more ("we have time to decide"), while Roberto Castelli (LN) claims to be ready for Lombardy, where the current president has decided to run again.

21 The CEI speaks of an "offense to humanity," referring to the confrontations in Lampedusa that led to the deaths of 73 immigrants. Italy and Malta blame each other.

In a letter sent in July, Napolitano urges the government to approve a program for the celebrations commemorating the 150th anniversary of the unification of Italy, in order to "reinforce our national identity." The LN replies: "We demand control over the expenses ... we are opposed to elephantine celebrations."

22 Bossi replies harshly to the criticism of the Church regarding the lack of aid for immigrants, claiming that "this does not make any sense ... the Vatican does not open its doors either."

23 At a meeting of the ecclesial movement Comunione e Liberazione (CL, Communion and Liberation), Frattini accuses the EU of "all words but no action" regarding migration policy. He states that the influx of refugees ought to be handled by all member states.

25 Immigration conflicts continue between the Church and the LN.

26 Fini assesses the LN's approach to immigration as "short-sighted, without any strategy." He also announces that he will take all possible steps to change the law on living wills.

27 Berlusconi reacts against La Repubblica for the 10 questions it poses daily on his sexual behavior ("rhetorical and clearly slanderous") and the forthcoming repercussions for politics. Franceschini: "You denounce not only La Repubblica-you denounce us all."

Several delegates of the PdL, including Gasparri and Quagliarello, criticize Fini's declarations regarding the living will.

28 A controversial article in Il Giornale condemns Dino Boffo for sexual harassment. Boffo is editor in chief of the CEI's L'Avvenire, a daily (affiliated with the Catholic Church) that had criticized Berlusconi's moral conduct. The CEI claims to have "complete trust" in Boffo. Berlusconi distances himself from the article. A dinner between Berlusconi and the secretary of the Vatican, Tarcisio Pietro Evasio Bertone, originally scheduled to celebrate the "ceremony of forgiveness" in L'Aquila, is canceled.

29 Cardinal Angelo Bagnasco, president of the CEI, describes the allegations of Il Giornale as "serious and disgusting."

Schifani's statement during a meeting of the CL ("it would be a mistake to condition parliamentarians through authoritarian interventions") is interpreted as a criticism of Fini's stance on the living will. 


\section{September}

1 After some EU commissioners criticize Italy's migration policy and stance on freedom of the press, Berlusconi reacts harshly: "Only the president of the European Commission ought to speak, not its spokesmen. Otherwise, we will forgo our support, block the functioning of the $\mathrm{EU}$, and demand the resignation of the commissioners."

2 Berlusconi sues L'Unita for slander in response to published articles about his recent whereabouts.

3 After days of bickering, Boffo resigns as editor of L'Avvenire. The CEI shows its solidarity: "Boffo has been the victim of an unspeakable attack."

6 There is a short encounter between the Pope and Letta, who declares afterwards that "the relationship between Italy and the Holy See is solid."

Tremonti criticizes the banks for having done too little to safeguard productivity and for having underutilized the "Tremonti bonds."

7 Il Giornale and Bossi criticize Fini for his proposal to grant immigrants the right to vote, the former referring to him as "Comrade Fini" and the latter calling him "insane." Berlusconi expresses "esteem for and closeness to" the president of the Chamber of Deputies.

8 Fini responds to Berlusconi, who denied the existence of problems between the two of them: "Not everything is settled. Some political problems still remain."

Berlusconi: "I know that there is judicial unrest in Palermo and Milan. It pains me that people like this, holding everyone's tax money, would conspire against those who work for the good of the country."

9 The Corriere della Sera publishes statements with regard to the investigation of the entanglement between politics, health, and prostitution in Puglia. It becomes clear that entrepreneur Gianpaolo Tarantini from Bari has brought approximately 30 girls to Berlusconi's parties, and that some may have been paid for sexual services. Tarantini has also brought women to Sandro Frisullo (PD), the former vice-president of Puglia, in exchange for favors, and has paid for an electoral dinner for D'Alema.

For the ANM, the declarations made by Berlusconi regarding judicial unrest are "unacceptable."

10 During the press conference of an Italian-Spanish meeting, Berlusconi declares "never to have paid for sex" and refers to himself as "the greatest statesman in the history of Italy." 
12 Fini responds to Bossi's most recent declarations and states that refusing to allow immigrants to exercise their rights is "a suicide of reason."

13 At an assembly, the UdC's leader, Pierferdinando Casini, declares that "bipartisanship is dead." Referring to the threats of the LN to call for early elections, he says that "it would take only $10 \mathrm{~min}$ utes" to find an alternative majority with the votes of 50 discontented deputies of the PdL.

In Venice, Bossi speaks of Padania as a "state that will be free, independent, and sovereign."

15 Fini undertakes action against Il Giornale, which had speculated that delegates of the AN would also be involved in a "red-light district" investigation.

Italo Bocchino and other delegates of the AN send a letter to Berlusconi in which they demand a "pact of permanent consultation" between Fini and the prime minister.

16 The state's attorney submits his memorandum to the Constitutional Court, which will assess the constitutionality of the Alfano law.

17 In Afghanistan, a car bomb kills six Italian soldiers. Bossi demands the withdrawal of Italian troops "by Christmas."

18 Berlusconi sheds light on the mission in Afghanistan and declares that there will be no "unilateral retreat." He states that a transition strategy is needed and should be reflected upon with the international community. Napolitano reacts: "There is no intention to cancel or rethink this mission. It is a shared burden."

21 A meeting takes place between Berlusconi and Fini. According to some, Fini reminded his ally that "the PdL was created by the two of us and should thus be managed accordingly," in an attempt to avoid future decisions being made during "dinners like the one on Monday," where the AN was excluded and the LN seemed to "dictate the direction of the government."

During the permanent council of the CEI, Bagnasco brings up the Boffo case (the Church "cannot be intimidated") and affirms that those who receive a political mandate must be "conscious of its scope and sobriety, its discipline and the honor that stems from it."

22 The financial law is presented. Tremonti states that it is only three articles with "zero cuts and zero taxes, only a photograph of the budget. The old financial regulations brought together correct and proper accounting rules and measures, which means intervention in the economy ... The correction of the economy has been done by means of various decrees this year."

The government also approves an enlarged "fiscal shield." With a sanction of 5 percent, it is now possible to repatriate or 
regularize previously undeclared capital held abroad and to be cleared of fiscal or corporate wrongdoing.

Berlusconi attacks the opposition ("proud of being anti-Italian-they are a fan of the crisis") and journalists ("I have urged the ministers not to respond to the gossip anymore").

In view of the PD congress, Franceschini criticizes the abundant expenses of Bersani and denounces the gerrymandering during the elections in Calabria.

23 The ANM expresses its disdain for the "fiscal shield."

Internal division within the PD regarding bioethics. Bianchi, who was disowned by the group leader Finocchiaro, resigns as spokeswoman for the Health Commission of the Senate due to conflicts regarding the survey on the abortion pill RU-486.

25 Controversy about the first episode of AnnoZero, in which Berlusconi's escapades with escort girls are discussed. Scajola wants to summon a meeting between the heads of the RAI ("garbage"). For Paolo Gentiloni (PD), this would be an "outlawed intervention."

26 Maroni attacks the European Union on immigration: "It scarcely acted and, when it did, acted wrongly."

28 Brunetta attacks the judiciary: "Chaos prevails in every court, and out of 14 there is nobody left." Harsh response from the ANM.

29 In the lower house, the government grants its confidence in the decree that extends the applicability of the "fiscal shield" to capital that is kept hidden abroad (including fiscal crimes). Harsh criticism from the opposition. Leoluca Orlando (IdV) addresses Napolitano because "he should not put up with a new Mafia arrangement for the state."

30 Berlusconi reacts to the demonstration to uphold the freedom of the press, which will be held on 3 October, describing it as "an absolute farce. In Italy there is more freedom of the press than in any other country."

Conflicts continue concerning the parliamentary procedure of the "fiscal shield." Fini's intention to make use of the so-called guillotine-the interruption of discussion in order to move on swiftly to the actual vote-provokes heated reaction.

\section{October}

1 AnnoZero hosts Patrizia D’Addario ("Berlusconi knew I was an escort"), stirring up the protests of the PdL.

2 Disaster in Messina leads to 18 deaths and 35 missing. Napolitano warns that the country does not need "pompous projects" but "a 
security plan" instead. Bertolaso blames the "water erosion damage caused by large-scale abuse."

The lower house approves the "fiscal shield" with only 20 opposing votes. If the entire opposition had been present, the measure would have been rejected.

3 In Rome, a demonstration to draw attention to the freedom of the press brings out 300,000 participants, according to the organizers, 60,000 , according to the police. An editorial written by Minzolini, the director of TG1, who is very critical of the demonstration, stirs up reactions.

4 After the civil court of Milan rules that Fininvest must pay 750 million euros to Compagnie Industriali Riunite (CIR, United Industrial Companies) of Carlo De Benedetti in connection with the so-called Mondadori law, Berlusconi ("one would want to escape abroad, but I will not let go") and other delegates of the PdL react harshly. Bondi speaks of a "concentric attack," while Cicchitto raises the possibility of a "large-scale demonstration."

7 The Constitutional Court rejects the Alfano law for violation of Articles 3 and 138. Berlusconi attacks the court and the head of state, characterizing them as "personifications of the old left." Franceschini: "There will be difficult days to come. Berlusconi will not obey the verdict of the court so easily."

8 Schifani and Fini meet with Napolitano. In a joint press release, they "acknowledge the president's rigorous respect of the prerogatives that the Constitution grants him."

9 Referring to the trials in which he is involved, Berlusconi declares that "certain judges" intend to "subvert the popular will." Regarding Napolitano: "Let us not pretend to be super partes. Napolitano has been a protagonist of the cause of the left." Nonetheless, Berlusconi deems it possible to be in a situation of "loyal coexistence" with the president of the Republic.

10 During a congress of the liberal-conservative think tank FareFuturo, Marcegaglia asks the government to lower the taxes on labor and urges Berlusconi not to "amplify the controversies but to focus instead on the problems of the country."

11 The national congress of the PD announces the definitive results of its elections: 55.1 percent for Bersani, 36.9 percent for Franceschini, and 7.9 percent for Marino. Franceschini, referring to Berlusconi's statement about Bindi ("she is more beautiful than intelligent"), describes the prime minister as "a petty man." Bersani: "We have to reopen the yard of the Olive Tree [Ulivo] and work toward a broad framework of alliances." 
During the liberation festivities in Benevento, Berlusconi attacks the foreign media for "tarnishing our democracy and our country." He warns: "They will not make me fall as they did in 1994."

12 After days of bickering (and indiscreet speculations in Il Giornale alluding to an arrangement by Napolitano to guarantee a favorable outcome of the Alfano law), an official note released by the presidential palace specifies that "it is incorrect to assume that a pact has been stipulated ... aimed at ensuring a favorable assessment of the constitutionality. The promulgation of a law ... could not in any way entail a guarantee of a favorable assessment of the court in the case of doubt."

13 Draghi asks to "raise the average effective pension age." Sacconi responds that "the already existing reforms will do." The president of the INPS, Antonio Mastrapasqua, also affirms that "the system holds."

Napolitano intervenes in conflicts regarding the rejection of the Alfano law: "Dating from the time that I became minister of internal affairs, I was no longer a man defending a certain ideological stance. I became a man defending the institutions instead."

The lower house votes on the law regarding homophobia and deems it unconstitutional. Controversy arises in the PD because Paola Binetti voted against the law. Franceschini: "Her presence in the PD is problematic."

15 The director-general of the Bank of Italy, Fabrizio Saccomanni, declares during a hearing in the Senate that the "fiscal shield" could have "negative effects on the incentives of the taxpayers to continue their contribution in the future." Tremonti excludes "reasons to be alarmed."

16 Berlusconi asserts that a constitutional reform of the judiciary is necessary, to be obtained by majority vote and possibly a confirming referendum.

Debate between the aspirant secretaries of the PD on YouDem.tv.

17 The ANM expresses its discontent with regard to the reform of the judiciary, as suggested by Berlusconi.

19 During an assembly, Tremonti declares that he believes "in contracts of indeterminate longevity, on the basis of which a project for one's life can be constructed."

Meeting between Galan, who wishes to run for president in Veneto again, and Berlusconi, who is urged by the LN to appoint his own delegate for the position.

20 Berlusconi claims to "agree completely" with the statements made by Tremonti regarding contracts of indeterminate longevity, whereas Marcegaglia deems them a "return to the past." 
21 Numerous people are arrested in Campania for corruption. Clemente Mastella, the leader of the Unione Democratici per l'Europa (UDEUR, Union of Democrats for Europe), and his wife Sandra Lonardo are involved in the investigations as well.

The European Parliament rejects two resolutions: one submitted by the PD and IdV in order to affirm that the freedom of the press is at risk in Italy, and another submitted by the European People's Party (EPP), according to which the freedom of the press is a well-respected right in Italy.

Berlusconi pays a "private visit" to Vladimir Putin. Criticism from Rutelli (chairman of the Parliamentary Committee for the Security of the Republic) for the secrecy behind the trip.

22 Berlusconi promises the abolition of the Imposta Regionale sulle Attività Produttive (IRAP, regional business tax). Franceschini: "These announcements are meant to cover up his lack of action." The unions urge the government to take care of the salaries and pensions first.

23 Four policemen are arrested for blackmailing Piero Marrazzo, who was filmed during his escapades with a transsexual. The president of Lazio admits to having paid the policemen "out of fear," but nevertheless says that the video is "a sham."

Tremonti is opposed to the abolition of the IRAP and, when confronted with the criticism of many of his fellow delegates of the majority, threatens to resign. Bossi: "There is an attempt to get rid of him, but I will protect him."

24 Marrazzo acknowledges the existence of the video and resigns as president of Lazio: "My presence is now no longer opportune."

In Arcore, Berlusconi meets first with Tremonti (to discuss the abolition of the IRAP and the suggestion that Tremonti might become vice-president of the Council of Ministers), then with Bossi ("as long as I am alive, Tremonti will not face any problems"), and lastly with Calderoli.

25 Primaries of the PD. Two and a half million participants. Results confirmed: Bersani wins (53.2 percent), followed by Franceschini (32 percent) and Marino (14.8 percent).

More on the Marrazzo case. Prior to the arrest of the policemen, the president of Lazio allegedly received a phone call from Berlusconi, who informed him about the existence of the video (the prime minister had been told about the video by the director of the Mondadori magazine $\mathrm{Chi}$ ).

26 Berlusconi meets with the coordinators of the PdL-Bondi, La Russa, and Denis Verdini-who are opposed to the promotion of Tremonti to vice-president of the Council, as requested by Bossi. 
27 Marrazzo resigns as president of Lazio.

Mills trial: confirmation that the English lawyer is to serve six and a half years in prison for corruption in judicial matters. Berlusconi responds in Ballarò: "The Italian anomaly is embodied by the Communists of Milan."

Meeting between Berlusconi and Tremonti: the finance minister will not have additional competences in the government, but will lead the Committee of Political Economy of the PdL.

During a press conference (at which Massimo Cacciari, the mayor of Venice, and Lorenzo Dellai, the president of Trento, are also present), Rutelli confirms his intentions to leave the PD.

28 Giuseppe Vegas, the vice-minister of economics and finance denies rumors that some senators of the PdL have been preparing for the abolition of the IRAP ("we simply do not have the numbers to accomplish this").

The Council of Ministers approves the so-called Gelmini decree, aimed at reforming universities.

Meeting between Bersani and Di Pietro. "There is mutual intention to work together," declares the secretary of the PD.

29 The president of the Senate's Finance Commission, Mario Baldassare, demands the abolition of the IRAP. The government refuses again.

30 Berlusconi claims to be willing to support the candidacy of D'Alema as high representative of foreign and security affairs of the European Union.

\section{November}

2 Berlusconi: "If Bersani were to change the register and to handle the reforms himself, I would be very happy."

3 In consideration of an Italian citizen's appeal, the European Court of Human Rights rules that all crucifixes should be removed from classrooms because they are "a curtailment of the freedom of religion." Staunch opposition from the CEI, the government ("this is an attack against the identity of our country"), and many delegates from the opposition.

4 Berlusconi announces his intention to see that the prime minister is directly elected ("this happens already in the material Constitution").

Conflict between Maroni and Tremonti on the funding of security. Maroni declares that he would vote together with the opposition if they were to propose "more funding for the police." Bossi tones it down: "Maroni will do whatever the LN tells him to do. 
We have run together with Berlusconi, not with the opposition. We will deal with Tremonti."

Bersani meets with Franceschini, suggesting that he become head of the PD in the lower house.

5 In the new book written by Bruno Vespa, the television journalist and host of Porta a Porta, Berlusconi responds to the 10 questions posed by La Repubblica (the newspaper, however, counters with "lack of truth" and "lies").

6 Statistics released by the Organisation for Economic Co-operation and Development (OECD) demonstrate that the Italian economy has been ahead of recovery in the past year.

Confindustria criticizes the government for cuts in the funding of broadband.

Casini meets with Berlusconi and reaffirms that the UdC will run for the regional elections "by itself."

8 La Russa tones down the declarations made by Bossi, who claimed that after the regional elections of 2010, the presidency of Piedmont and Venice would be assigned to the LN. La Russa: "These aspirations are legitimate, but we ought to come to a mutual agreement."

9 The judge dealing with preliminary investigations in Rome asks the lower house for authorization to arrest Nicola Cosentino, undersecretary of the economy, coordinator of the PdL, and a likely candidate for the presidency of Campania. The investigation concerns illegal garbage disposal: Cosentino has been implicated by six local Mafiosi-turned-informants.

10 Meeting between Berlusconi and Fini regarding the judiciary. The president of the lower house rejects the possibility of "short limitations," as suggested by Berlusconi's entourage, while he agrees to the "short procedure" (which entails two years for every degree of sentence) and states that parliamentary immunity would not be "a scandal."

Fini declares that Cosentino's candidacy to be president of Campania "no longer belongs in the realm of possibilities."

11 Margherita Boniver (PdL) presents a bill to reintroduce parliamentary immunity.

A bill on the reform of the financial law is voted on in the lower house. The government is defeated twice over the amendments suggested by the PD and the IdV.

Rutelli's new party, Alleanza per l'Italia (ApI, Alliance for Italy), is founded. On board are Dellai, Bruno Tabacci (ex-UdC), and Pino Pisicchio (ex-IdV).

12 The bill on accelerated judicial procedures ("short procedure" or processo breve) is presented in the Senate. The measure introduces 
a statute of limitations two years after judicial proceedings are initiated. Harsh criticism from the opposition ("unconstitutional," maintain the PD and the IdV) and the ANM.

Cosentino meets with Berlusconi: "I will remain a candidate for Campania."

13 Casini opposes the "short procedure," describing it as "rubbish." He declares that an "Alfano law redux" through constitutional means would be better.

The Senate approves the law on finance. Schifani blocks (because of non-involvement in the matter) the norm (as it was wanted by Tremonti) regarding the Bank of the South. Discussions on the disappearance of funding for research. For Tremonti "there will be room for further reflections" in the lower house.

14 Delegates of the PdL (Schifani and Gaetano Pecorella) express their doubts regarding the bill on the "short procedure."

Governmental sources reveal that some Islamic threats addressed to Berlusconi have been intercepted.

Rome: demonstration of CGIL against the law on finance.

15 Domenico Raccuglia, a fugitive for 15 years who is considered to be "number two" in the Mafia, is arrested.

During an appearance on In Mezz'ora, Fini speaks of a "paroxysmal climate" in the PdL and rejects the accusations of some center-right newspapers, which interpret it as a plot against Berlusconi.

16 Bersani points out the course that the PD ought to sail. The PD will not take part in the "No B Day" (No Berlusconi Day) demonstrations that are scheduled for 5 December and are supported by Di Pietro.

17 Schifani's statement ("if the majority is not united, we will vote again") seems to confirm the speculations surrounding Berlusconi that early elections might be held.

18 Official note from Berlusconi: "I have never thought of early elections ... the majority is solid as a rock."

Thrust and counter-thrust on the immigration issue between Bossi ("they need to be sent back home") and Fini ("closing the borders is against any common sense").

19 Briton Catherine Ashton is appointed high representative of foreign and security affairs of the European Union. According to Martin Schulz, the head of the Party of European Socialists (PES), the defeat of D'Alema is due to the poor support of the Italian government.

20 Brenda, a transsexual involved in the Marrazzo case, is found dead. The public prosecutors initiate a homicide investigation. 
21 Fini meets with children of immigrants and states that people who discriminate are "assholes."

22 In an interview with Corriere della Sera, Brunetta attacks Tremonti ("he has overstepped his own competences ... he has become the chief of police of the government"). Bonaiuti responds: "The direction of the political economy of Minister Tremonti is inspired by the prime minister and shared by the entire government."

Casini proposes that, instead of the "short procedure," a law should be approved that would block the procedures of the prime minister for "legitimate impediments."

23 The ANM declares that, in some large judicial districts, the "short procedure" would lead to the suspension of 50 percent of pending procedures, due to the statute of limitations. For Alfonso, this would be a "sensational blunder. Do not play with numbers."

24 Fini: "The short procedure is not a proper reform of the judiciary." Regarding the institutional reforms, he asserts that, if the PD were willing to do so, it would be possible to start from the "Violante draft." Bersani: "Wise words."

25 Fini demands that, with regard to the financial law, the government should not be confined by "bulletproof texts."

The committee responsible for authorization rejects the request to arrest Cosentino. The Senate dismisses the lack of confidence motion against the undersecretary, as presented by the PD, the UdC, and the IdV.

26 Berlusconi: "There is a climate of civil war. The public prosecutors want to see me fall."

Anonymous letter in which the Mafia threatens Schifani.

The Commission of Health in the Senate blocks the sale of the abortion pill RU-486 and demands an assessment by the government. The PD and some delegates from the PdL protest.

Casini warns the PD that if they want an alliance for the regional elections, they will have to get rid of the "cacicchi, Vendola, Bresso, Loiero."

27 Napolitano demands a halt to "the increasing tensions between judges and politicians."

28 After some indiscretions in the press, speculating that Berlusconi would have received a notice of investigation regarding his alleged involvement in the bloodshed of the Mafia, the prosecutor of Florence declares that Berlusconi and his senior adviser, Marcello Dell'Utri, "have not been investigated."

29 Berlusconi restates his non-involvement with the Mafia ("despicable allegations ... my government has done the most for the struggle against organized crime") and announces legal action 
against the publishing group La Repubblica-L'Espresso for having assumed these links with the Mafia.

\section{December}

1 The Web site of La Repubblica publishes an off-the-record conversation (dating back to 6 November) between Fini and Nicola Trifuoggi, the prosecutor of Pescara, about Berlusconi. Fini: "He confuses the popular support he can count on with a sense of immunity"; the revelations regarding the Mafia "are shocking." Berlusconi: "He should either back down, or I do not ever want to see him again."

Harsh criticism from Casini and Piero Fassino, head of the PD's Foreign Affairs Department, with regard to Berlusconi's praise for Belorussian President Aleksandr Lukashenko during his visit to Belarus.

After the consumer union Coordinamento delle Associazioni per la Difesa dell'Ambiente e dei Diritti degli Utenti e dei Consumatori (CODACONS, Coordination of the Associations for the Defense of the Environment and for the Rights of Users and Consumers) demonstrates against the levels of pollution, the prosecutor of Milan starts an investigation against the president of Lombardy, Roberto Formigoni, the mayor of Milan, Letizia Moratti, and the president of the province, Guido Podestà.

2 Various delegates of the PdL criticize Fini. Scajola: "He is out of the party."

4 The Mafioso-turned-informant Gaspare Spatuzza testifies at the trial of Dell'Utri and, regarding the bloodshed of 1992-1993, claims that Berlusconi was involved. Berlusconi: "Insane allegations."

5 Two condemned and fugitive Mafiosi, Giovanni Nicchi and Gaetano Fidanzati, are arrested. Berlusconi: "Two extraordinary strikes. A response to those who slander me."

"No B Day" in Rome: a million participants, according to the organizers, 90,000, according to the police. Among the participants are some PD delegates, including Bindi, now president of the PD.

6 Criticizing Bersani's decision not to take part in "No B Day," Veltroni states: "It is wrong to say we only take part in demonstrations that we have organized."

7 The Budget Commission in the lower house approves the financial law. The opposition leaves the sitting, accusing the majority of not allowing enough time for discussion.

9 The ANM announces plans to mobilize against the bill on the "short procedure," which has also been criticized by the CSM. 
Alfano attacks the judges: "You ought to spend more time investigating and less time on television."

Bersani refers to the probable decision of the government to grant its confidence to the financial law as "a body blow to the Parliament."

10 During a meeting of the EPP, Berlusconi announces that he wants to change the Constitution: "The sovereignty has passed on from the Parliament to the judges. The Constitutional Court has been transformed into a political institution." Harsh reactions from Napolitano and Fini.

11 At the Dell'Utri trial, Mafia boss Filippo Graviano denies what Spatuzza claims: "I have never known Dell'Utri." Berlusconi: "This is a comedy."

12 Casini affirms that, if early elections were to be held, a "Republican front," ranging from the UdC to Di Pietro, would be needed against Berlusconi. Bersani agrees. Di Pietro: "Impossible. There will be no early elections."

13 Milan: after a meeting, while walking through the masses, Berlusconi is attacked by Massimo Tartaglia, a man who suffers from psychological disorders. Tartaglia strikes Berlusconi in the face with a metal replica of a statue. Controversial statements made by Di Pietro ("Berlusconi instigates a climate of violence with his negligence").

14 Fini and Bersani visit Berlusconi in the hospital. Napolitano appears on television (TG2): "We need to put an end to this exasperation of political bickering ... we need to be civil again." The PdL accuses the PD of having fueled a "climate of hatred" (referring to the aggressive criticism of Berlusconi's remarks about Bindi). The PD responds: "Berlusconi is among the authors of this climate and should not victimize himself."

The CSM adopts a negative stance regarding the bill on the "short procedure."

15 Fini finds the government's decision to grant its confidence to the financial law "appalling." He harshly criticizes the tone used by the PdL during the parliamentary debate about the attack on Berlusconi, assessing as a "Molotov cocktail" the discourse of Cicchitto, who ascribes the "responsibility" for the current climate to the dailies La Repubblica-L'Espresso and Il Fatto Quotidiano, the talk show programs and journalism of Santoro and Marco Travaglio, and some public prosecutors.

16 After a long discussion, the PdL announces that in Piedmont and Veneto, delegates of the LN will run for elections. For Galan, this is a "betrayal ... every decision was made in Rome." 
The regional councilor of Lombardy, Pier Gianni Prosperini, is arrested for corruption and fraud.

17 Berlusconi is discharged from the hospital. Official press release from the Palazzo Chigi: "If from these events a major consciousness were to develop that we ought to engage in calm discussion ... my pain will not have been in vain."

18 At a meeting of Area Democratica, a faction of the PD that supports Franceschini, D'Alema is criticized for his declaration that "certain deals," such as Article 7 of the Constitution, "would still be useful today." Franceschini: "We do not want to mismanage the reforms."

The PdL in Veneto disagrees with the candidacy of a delegate from the LN rather than Galan.

The coordinators of the PdL turn to Lombardo, who is working on the formation of a third coalition government in Sicily, based on a change in majority, asking him to "exclude any possible reversal."

20 In an interview with Corriere della Sera, Tremonti states that "the moment of reform has arrived. A common constituting commitment" would have "a pacifying effect."

21 Napolitano expresses the hope that "common ground for reform will be found," but adds that "a favorable climate has yet to be unfolded."

22 Berlusconi declares his willingness to forgive his aggressor and hopes that "the dialogue can now take off again. The "Violante draft' provides a solid basis."

Marchionne presents Fiat's industrial plans to the government and the unions. Demonstrations of workers, who are concerned about the fate of their factories in Pomigliano d'Arco and Termini Imerese. Scajola-who, on 24 November had stated that it would be "unthinkable" to shut down Termini Imerese-asks the firms, unions, and local entities for a "joint effort."

23 In his "letter to Santa Claus" published on his blog, Di Pietro states, with regard to the anticipated reforms, that "one cannot engage in a dialogue with the devil, and in our country we have a devil at the head of our government."

26 Berlusconi assures that in 2010 "we will succeed in every institutional reform." Bersani: "A biased assessment of these reforms can only come from them. It will depend on whether or not measures will be undertaken in January."

28 Al-Qaeda claims responsibility for the abduction of two Italians in Mauritania, "in response to the actions of Italy in Iraq and Afghanistan.” 
Difficulties within the PD in Puglia: Vendola's supporters, who demand primaries to be held, provoke the crumbling of the assembly that was intended to choose the candidate for the regional elections.

29 Statistics of the Ministry of Economy and Finance reveal that the "fiscal shield" has led to the repatriation of 95 billion euros, "which accounts for 6 percent of the GDP." For the government, this is "an extraordinary victory."

The PD decides that the candidate for the regional elections in Puglia will be chosen through primary elections, for which both Vendola and Michele Emiliano are candidates. The UdC, willing to reach an agreement with Emiliano, describes the behavior of Vendola's supporters as "political gangsterism."

31 In his end-of-year-speech, Napolitano urges the political forces to push through certain indispensible reforms-social shock absorbers, judicial and institutional reforms that "cannot be held back because of a climate of suspicion and biased opposition."

- Translated by Laura Beke 